\title{
Antimicrobial resistance and extended spectrum beta-lactamases in urinary tract infections: A serious problem in Northern Mexico
}

\section{Resistencia antibiótica y agentes beta-lactamasa de espectro extendido en las infecciones del tracto urinario: un problema grave en el norte de México}

\author{
iD José Iván Robles-Torres, ${ }^{1 *}$ iDMarco Alberto Ocaña-Munguía, ${ }^{1}$ iDedro Antonio Madero Morales, ${ }^{1}$ \\ iDEfraín Ruiz-Galindo, ${ }^{1}$ iDElvira Garza-González, ${ }^{1}$ iD Lauro Gómez-Guerra. ${ }^{1}$
}

Keywords:

Extended spectrum

beta-lactamase, Urinary

tract infections, Drug

resistance, Urine

culture

Corresponding:

*José Iván Robles-To-

rres. Dr. José Eleuterio

González (Gonzalitos)

S/N, Mitras Centro, 64460 Monterrey, N.L. Email: ivan.robles25@

live.com

\section{Abstract}

Objective: To describe the causal agents, prevalence of antimicrobial resistance, and risk factors associated with extended spectrum beta-lactamase (ESBL)-producing agents in urinary tract infections (UTIs).

Materials and methods: A retrospective study was conducted at a tertiary care hospital in Monterrey, Mexico. Inclusion criteria were patients that clinically presented with a UTI and had a positive urine culture, within the time frame of March to October 2017. The association with ESBL-producing agents was determined through the X2 test for categorical variables. Statistical significance was set at a $\mathrm{p}<0.05$, utilizing SPSS version 20.0 software.

Results: A total of 353 positive urine cultures were confirmed. ESBL production was found in $21.5 \%$ of the strains. There was a high level of resistance $(>50 \%)$ to amoxicillin-clavulanate, ciprofloxacin, levofloxacin, fosfomycin, and trimethoprim-sulfamethoxazole and moderate resistance (10-50\%) to gentamicin and ceftriaxone. Amikacin, ertapenem, nitrofurantoin, and colistin had the lowest resistance rates $(<10 \%)$. The ESBL-producing agents were associated with complicated UTI $(\mathrm{p} \leq 0.0001)$. The comorbidities associated with ESBL-positive UTIs were diabetes mellitus $(p=0.02)$ and immunodeficiency $(p=0.008)$, as was having undergone radiotherapy $(\mathrm{p}=0.025)$ and previous antibiotic use $(\mathrm{p} \leq 0.001)$.

Limitations: The clonal relationship of isolates, especially of E. coli, was not analyzed. We could not establish whether there was a high level of genetic diversity between the isolates or whether independent acquisition or cross-transmission occurred.

Value: We evaluated the epidemiologic characteristics of the ESBL-producing agents in UTIs at a Mexican tertiary care hospital.

Conclusions: One out of every five UTIs was caused by ESBLs in our study population. There was a high level of resistance to the antibiotics used as first-line empiric therapy in the patients studied.

Citación: Robles-Torres J.I., Ocaña-Munguía M.A., Madero-Morales P.A., Ruiz-Galindo E., Garza-González E., Gómez-Guerra L. Antimicrobial resistance and extended spectrum beta-lactamases in urinary tract infections: A serious problem in Northern Mexico. Rev. Mex. Urol. 2020;80(2):pp 1-12

${ }^{1}$ Universidad Autónoma de Nuevo León, Hospital Universitario Dr. José Eleuterio González, Monterrey, Nuevo León, México.

Received: April 03, 2020

Accepted: April 24, 2020

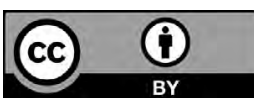




\section{Resistencia antibiótica y agentes beta-lactamasa de espectro extendido en las infecciones... Robles-Torres J. I., et al.}

\section{Resumen}

Objetivo: Describir los agentes causales, la prevalencia de resistencia a antibióticos y determinar factores de riesgo asociados con agentes productores de betalactamasa de espectro extendido (BLEE) en las infecciones del tracto urinario (ITU).

Materiales y métodos: Realizamos una cohorte retrospectiva en un hospital de III Nivel en Monterrey, México. Se incluyeron pacientes con clínica de ITU de marzo a octubre del 2017 con urocultivo positivo. Se determinó la asociación con agentes productores de BLEE, utilizando la prueba X2 para variables categóricas y la prueba T para variables continuas. La significancia estadística se estableció en $\mathrm{p}<0.05$ utilizando SPSS versión 20.0.

Resultados: 353 urocultivos positivos fueron recabados. La producción de BLEE se encontró en $21.5 \%$. Altas resistencias a amoxicilina-clavulanato (75\%) y moderada resistencia a gentamicina, aztreonam, ceftriaxona, ciprofloxacina, levofloxacina, fosfomicina y trimetoprima-sulfametoxazol fueron encontradas. Los agentes BLEE se asociaron con ITU complicada $(p=<0.0001)$ y se asociaron con DM2 $(p=0.02)$, inmunodeficiencia $(p=0.008)$, radioterapia $(p=0.025)$ y uso previo de antibióticos $(\mathrm{p}=<0.001)$.

Limitaciones: La relación clonal de los aislamientos, especialmente de E. coli, no se analizó. No podemos establecer si hubo diversidad genética entre los aislamientos y si ocurrió adquisición independiente o transmisión cruzada.

Palabras clave:

Betalactamasa de espectro extendido, infecciones del tracto urinario, Resistencia a antibióticos, urocultivo Valor: Evaluamos las características epidemiológicas de los agentes productores de BLEE en ITU en un hospital de III Nivel de México. Conclusiones: Una de cada cinco ITU es causada por agentes BLEE en nuestra población. Existe una alta resistencia a los antibióticos usados como terapia empírica en nuestra población.

\section{Introduction}

Urinary tract infections (UTIs) are among the most prevalent community-acquired and hospital-acquired infections. ${ }^{(1)}$ An estimated 1 million cases of nosocomial UTIs occur in the United States annually, accounting for considerable morbidity and healthcare costs. ${ }^{(2)}$ In
Mexico, UTIs are the third cause of infectious diseases, surpassed only by upper respiratory tract infections and gastrointestinal infections. (3) No structural or functional abnormalities in the genitourinary tract or relevant comorbidities are related to an uncomplicated UTI. A 
Resistencia antibiótica y agentes beta-lactamasa de espectro extendido en las infecciones... Robles-Torres J. I., et al.

complicated UTI is associated with a condition of the genitourinary tract or the presence of an underlying disease, which increases the risk of a more serious outcome. . $^{(1,4)}$

The most common agent causing UTIs is Escherichia coli (E. coli). ${ }^{(1,4)}$ However, complicated UTIs are caused by a greater variety of agents with higher antibiotic resistance rates, and a higher frequency of failure to empiric treatment. ${ }^{(5,6)}$ In recent years, increased drug resistance has been reported worldwide, including the emergence of extended spectrum $\beta$-lactamase (ESBL)-producing agents in Enterobacteriaceae, mainly E. coli and Klebsiella pneumoniae. ${ }^{(7,8)}$ ESBLs confer resistance to penicillins, cephalosporins, and aztreonam. ${ }^{(9,10)}$

Few studies have reported the risk factors associated with UTIs caused by ESBL-producing E. coli, such as diabetes, recurrent UTIs, urinary catheterization, genitourinary pathology, previous bacterial infection, intravenous antibiotic treatment, hospitalization, and previous antibiotic therapy. ${ }^{(11-13)}$

The prevalence of ESBL-producing bacteria in UTIs is heterogeneous and dependent on geographic region. ${ }^{(14)}$ Therefore, the aim of the present study was to determine the etiologic agents, antimicrobial resistance rates (including ESBL-producing bacteria), and risk factors associated with ESBL-positive UTIs at a tertiary care hospital in Northern Mexico.

\section{Materials and methods}

\section{Setting and study population}

A retrospective cohort study was performed at a tertiary care teaching hospital in Monterrey, Mexico. Approval by the Local Ethics Commi- ttee was previously established (UR14-004). Inclusion criteria included positive urine cultures with signs and symptoms of UTI from outpatients and hospitalized patients, within the time frame of March to October 2017. Asymptomatic bacteriuria, incomplete clinical records, and urine cultures with two or more causative agents were excluded. UTI classification was based on the European Association of Urology (EAU) criteria, as either complicated or uncomplicated, and hospital-acquired UTIs (HA-UTIs) or community-acquired urinary tract infections (CA-UTIs). ${ }^{(4)}$

\section{Antimicrobial susceptibility and ESBL determination}

Species identification of urine isolates was performed using MALDI-TOF mass spectrometry (Microflex, Bruker Daltonics). Drug resistance of $E$. coli isolates was determined by the microdilution plate method for all drugs except fosfomycin, which was established through the agar dilution method. The results were interpreted according to the Clinical and Laboratory Standards Institute (CLSI) criteria. ${ }^{(15)}$ The antibiotics tested were amikacin, gentamicin, amoxicillin-clavulanic acid, aztreonam, ceftriaxone, ertapenem, ciprofloxacin, levofloxacin, nitrofurantoin, fosfomycin, trimethoprim-sulfamethoxazole, and colistin. Carbapenem-resistant isolates were screened to detect carbapenemase production using the CarbaNP test. ${ }^{(15)}$ The production of ESBL in E. coli and Klebsiella spp. isolates was performed using the double-disc test, according to the CLSI. ${ }^{(15)}$ 


\section{Resistencia antibiótica y agentes beta-lactamasa de espectro extendido en las infecciones... Robles-Torres J. I., et al.}

\section{Statistical analysis}

Categorical variables were expressed in frequencies and percentages. Numerical variables were expressed as a mean and standard deviation. Clinical and demographic characteristics were analyzed using the $\chi 2$ test for the categorical variables, and the T-test (or Mann-Whitney $\mathrm{U}$ test in the absence of normal distribution) for the continuous variables. Statistical significance was set at a $\mathrm{p}<0.05$. The statistical analysis was performed utilizing SPSS version 20.0 software.

\section{Results \\ Study population and UTI causative agents}

A total of 353 patients were included. Their median age was 47.3 years, and females were the most affected $(64.3 \%, n=227)$. CA-UTIs were the most frequently detected UTIs, accounting for $65.4 \%(n=231)$, and $34.5 \%(n=122)$ were HA-UTIs. Of the HA-UTIs, 91.8\% $(\mathrm{n}=112)$ were complicated, and $8.2 \%(\mathrm{n}=10)$ were uncomplicated. Regarding the CA infections, 73.6\% ( $\mathrm{n}=170)$ were complicated UTIs and 26.4\% (n=61) were uncomplicated (Figure 1).

Figure 1. Classification of the HA-UTIs, CA-UTIs, and the complicated and uncomplicated UTIs in the study population, as well as the distribution of the ESBL-producing agents.

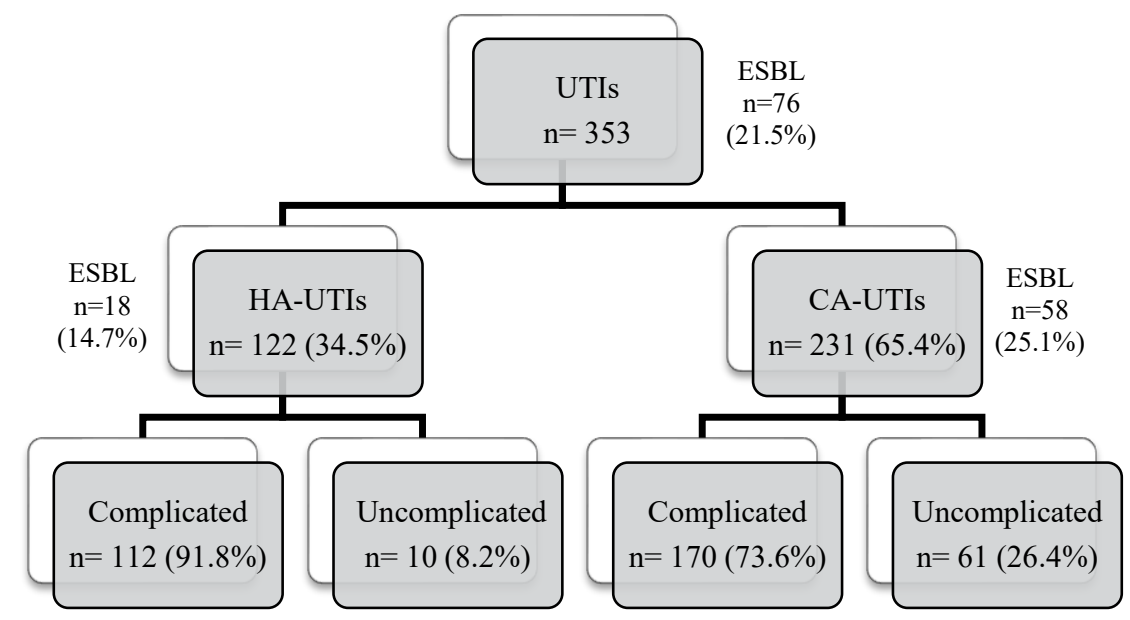

The clinical data of the study population are shown in Table 1 . The most common underlying factors were previous use of antibiotics $(41.6 \%, \mathrm{n}=147)$, type 2 diabetes $(32.3 \%$, $\mathrm{n}=114)$, and chronic renal disease $(18.1 \%$, $\mathrm{n}=64)$. The most frequent agent was $E$. coli ( $57.2 \%, \mathrm{n}=202)$, followed by Candida sp. (9.9\%, $\mathrm{n}=35)$ and Klebsiella spp. (9.1\%, $\mathrm{n}=32)$. ESBL-producing agents were isolated in $21.5 \%$ of the total UTIs $(76 / 353)$, and $25.1 \%$ of the
CA-UTIs were ESBL producers (58/231), compared with $14.7 \%$ of the HA-UTIs (18/122). A total of $37.1 \%(n=131)$ of the patients had a urinary catheter, and $35.1 \%(\mathrm{n}=125)$ had a recurrent UTI. Complicated UTIs ( $\mathrm{p}<0.001)$, males $(\mathrm{p}=0.027)$, previous antibiotic use $(<0.001)$, immunodeficiency $(\mathrm{p}=0.015)$, and urinary catheter $(p<0.001)$ were more frequent in the HA-UTIs, whereas E. coli $(\mathrm{p}<0.001)$, uncomplicated UTIs $(\mathrm{p}<0.001)$, pregnancy $(\mathrm{p}=0.008)$, 
recurrent UTIs $(\mathrm{p}=0.01)$, urosepsis $(\mathrm{p}=0.002)$, and lithiasis $(\mathrm{p}=0.041)$ were more frequent in the CA-UTI group. In addition, we detected an association between the presence of urinary catheter and Candida sp. infection (21.3\%) $(\mathrm{p}<0.001$, data not shown).

Table 1. Characteristics of the study population and HA-UTI and CA-UTI sub-classification.

\begin{tabular}{|c|c|c|c|c|c|}
\hline Characteristic & $\begin{array}{c}\text { Total } \\
(n=353) \\
\end{array}$ & $\begin{array}{c}\text { HA-UTI }(n=121, \\
34.3 \%)\end{array}$ & $\begin{array}{c}\text { CA-UTI }(n=232, \\
65.7 \%)\end{array}$ & P value & OR $(95 \% \mathrm{CI})$ \\
\hline \multicolumn{6}{|l|}{ Causative agent } \\
\hline E. coli & $202(57.2)$ & $44(21.8)$ & $158(78.2)$ & $<0.001$ & $0.26(0.16-0.41)$ \\
\hline Klebsiella spp. & $32(9.1)$ & $12(37.5)$ & $20(62.5)$ & 0.714 & $1.15(0.54-2.44)$ \\
\hline Other* & $180(51.0)$ & $66(36.7)$ & $114(63.3)$ & ND & ND \\
\hline \multicolumn{6}{|l|}{ Demographics } \\
\hline Male & $126(35.6)$ & $53(42.1)$ & $73(57.9)$ & 0.027 & $1.66(1.06-2.62)$ \\
\hline Age $\geq 60$ years & $120(34.0)$ & $41(34.2)$ & $79(65.8)$ & 0.911 & $0.97(0.61-1.55)$ \\
\hline \multicolumn{6}{|l|}{ UTI type } \\
\hline Complicated & $282(79.9)$ & $112(39.7)$ & $170(60.3)$ & $<0.001$ & $4.02(1.98-8.17)$ \\
\hline Uncomplicated & $71(20.1)$ & $10(14.1)$ & $61(85.9)$ & $<0.001$ & $0.25(0.12-0.51)$ \\
\hline \multicolumn{6}{|l|}{ Underlying factors } \\
\hline $\begin{array}{c}\text { Previous use of } \\
\text { antibiotics }\end{array}$ & $147(41.6)$ & $66(44.9)$ & $81(55.1)$ & $<0.001$ & $2.18(1.40-3.41)$ \\
\hline Type 2 diabetes & $114(32.3)$ & $37(32.5)$ & $77(67.5)$ & 0.576 & $0.87(0.54-1.40)$ \\
\hline Chronic renal disease & $64(18.1)$ & $28(43.8)$ & $36(56.3)$ & 0.088 & $1.61(0.93-2.90)$ \\
\hline Arterial hypertension & $56(15.9)$ & $15(26.8)$ & $41(73.2)$ & 0.183 & $0.65(0.34-1.23)$ \\
\hline Immunodeficiency & $29(8.2)$ & $16(55.2)$ & $13(44.8)$ & 0.015 & $2.53(1.18-5.46)$ \\
\hline Pregnancy & $27(7.6)$ & $3(11.1)$ & $24(88.9)$ & 0.008 & $0.22(0.06-0.74)$ \\
\hline \multicolumn{6}{|l|}{ Urologic alterations } \\
\hline Catheter & $131(37.1)$ & $81(61.8)$ & $50(38.2)$ & $<0.001$ & $7.15(4.39-11.66)$ \\
\hline Recurrent UTI & $124(35.1)$ & $32(25.8)$ & $92(74.2)$ & 0.011 & $0.54(0.33-0.87)$ \\
\hline Urosepsis & $51(14.4)$ & $8(15.7)$ & $43(84.3)$ & 0.002 & $0.31(0.14-0.68)$ \\
\hline Obstructive uropathy & $49(13.9)$ & $12(24.5)$ & $37(75.5)$ & 0.110 & $0.57(0.29-1.14)$ \\
\hline Urologic surgery & $44(12.5)$ & $15(34.1)$ & $29(65.9)$ & 0.944 & $0.98(0.50-190)$ \\
\hline Lithiasis & $29(8.2)$ & $5(17.2)$ & $24(82.8)$ & 0.041 & $0.37(0.14-0.99)$ \\
\hline Neurogenic bladder & $28(7.9)$ & $9(32.1)$ & $19(67.9)$ & 0.779 & $0.89(0.39-2.02)$ \\
\hline $\begin{array}{ll}\text { Benign } & \text { prostatic } \\
\text { hyperplasia } & \\
\end{array}$ & $25(7.1)$ & $6(24.0)$ & $19(76.0)$ & 0.250 & $0.58(0.22-1.49)$ \\
\hline Tumor & $18(5.1)$ & $4(22.2)$ & $14(77.8)$ & 0.259 & $0.53(0.17-1.63)$ \\
\hline $\begin{array}{l}\text { Radiotherapy and/or } \\
\text { chemotherapy }\end{array}$ & $10(2.8)$ & $4(40.0)$ & $6(60.0)$ & 0.714 & $1.27(0.35-4.59)$ \\
\hline
\end{tabular}

*Other pathogens include: Candida sp. $(\mathrm{n}=35)$, Enterococcus sp. $(\mathrm{n}=27)$, Pseudomonas aeruginosa $(\mathrm{n}=18)$, Staphylococcus aureus $(n=7)$, Proteus mirabilis $(n=6)$, Acinetobacter baumannii $(n=4)$, Providencia rettgeri $(n=3)$, Pseudomonas sp. $(\mathrm{n}=3)$, Staphylococcus saprophyticus $(\mathrm{n}=3)$, Streptococcus sp. $(\mathrm{n}=3)$, Streptococcus agalactiae $(\mathrm{n}=2)$, Morganella morganii $(\mathrm{n}=2)$, Burkholderia cepacia $(\mathrm{n}=1)$, Citrobacter freundii $(\mathrm{n}=1)$, Enterobacter aerogenes $(\mathrm{n}=1)$, Enterobacter cloacae $(\mathrm{n}=1)$, Myroides odoratus $(\mathrm{n}=1)$ and Stenotrophomonas maltophilia $(\mathrm{n}=1)$.

ND, not determined; HA-UTI, hospital-acquired urinary tract infection; CA-UTI, community-acquired urinary tract infection. 
Microbiologic characteristics and antibiotic susceptibility profile

The most common causative agent was $E$. coli $(57.2 \%, 202 / 353)$ of both HA-UTIs and CA-
UTIs, accounting for $36 \%(44 / 122)$ and $68 \%$ (158/231), respectively. The rest of the causal agents are shown in figure 2. A greater variety of causative agents was observed in the HAUTIs.

Figure 2. Uropathogenic agents of HA-UTIs (a) and CA-UTIs (b) from 353 positive urine cultures
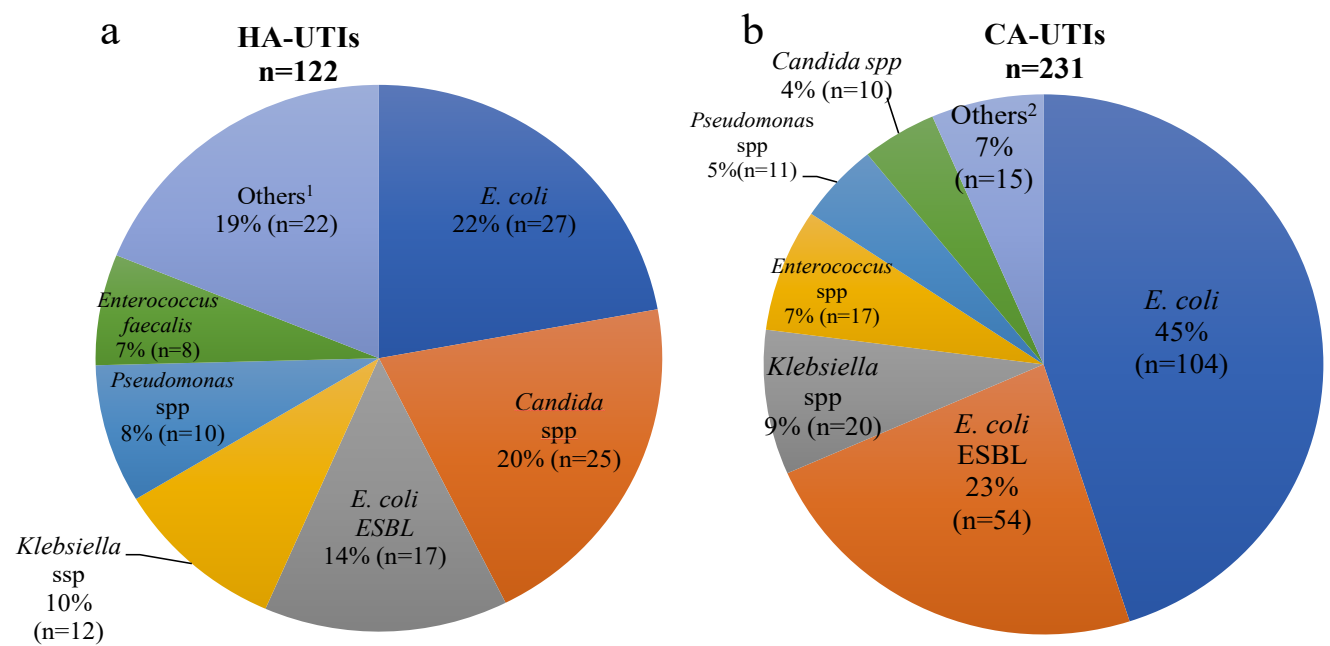

${ }^{1}$ Staphylococcus spp, Enterobacter spp, Providencia rettgeri, Burkholderia cepacia, Citrobacter freundii, Myroides odoratus, Stenotrophomonas maltophilia, Acinetobacter baumanii, Proteus mirabilis, Streptococcus spp.

${ }^{2}$ Morganella morgagni, Proteus mirabilis, Enterobacter spp, Providencia rettgeri, Streptococcus spp, Staphylococcus spp.

HA-UTIs: hospital-acquired urinary tract infections; CA-UTIs: community-acquired urinary tract infections.

Antibiotic susceptibility patterns are described in Figure 3. The drugs with a high resistance rate $(>50 \%)$ were amoxicillin-clavulanate (77\%), fosfomycin (62\%), ciprofloxacin (60\%), trimethoprim-sulfamethoxazole (59\%), levofloxacin (56\%), and aztreonam (52\%). Amika- cin (1\%), ertapenem (3\%), colistin (4\%), and nitrofurantoin $(8 \%)$ were the antibiotics that presented the lowest resistance $(<10 \%)$. Moderate resistance (10-50\%) was observed with gentamicin (37\%) and ceftriaxone (48\%). 
Figure 3. Escherichia coli susceptibility pattern in UTIs by the plate microdilution method from 180 samples [n (\%)].

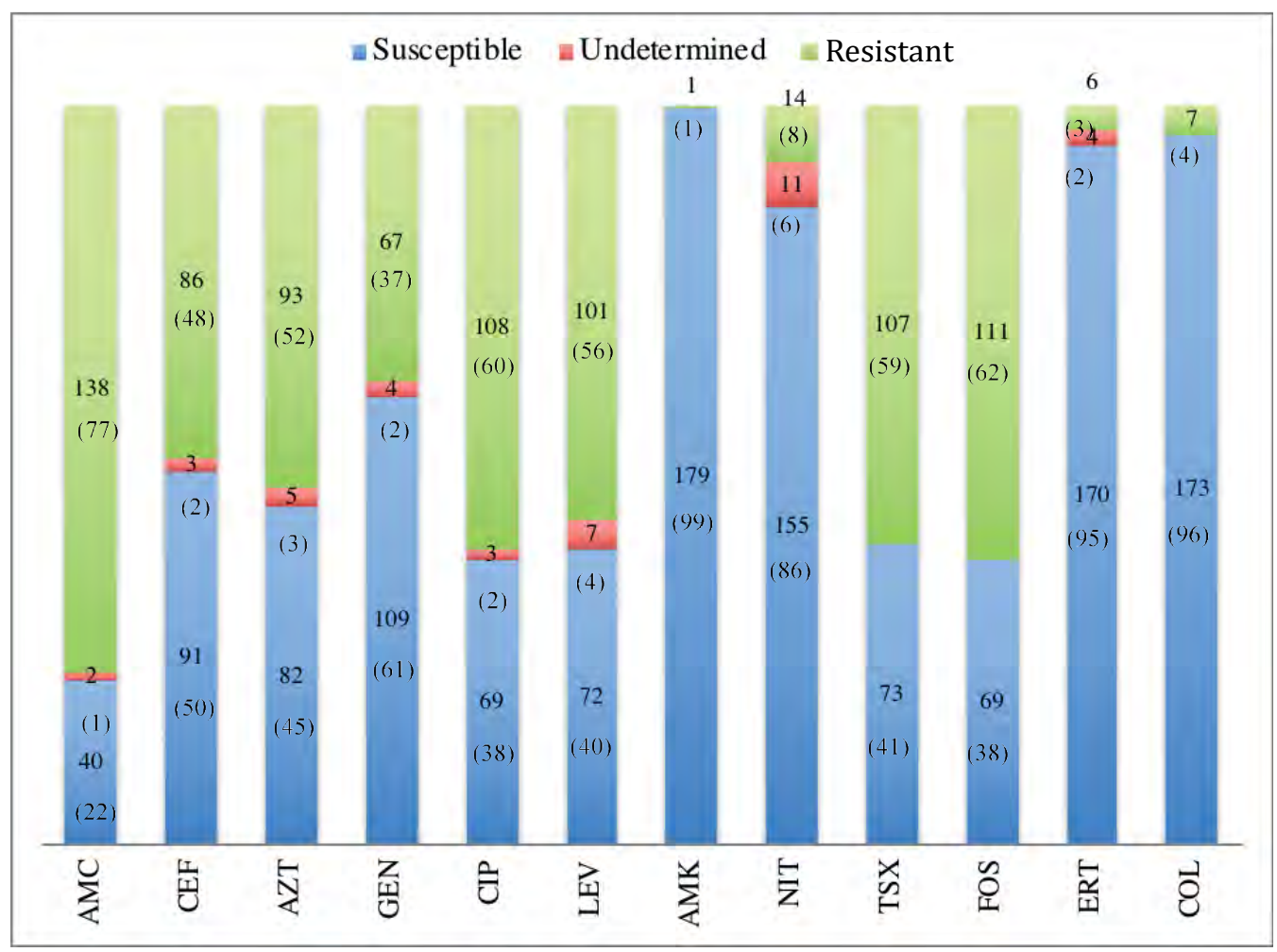

$\mathrm{AMC}=$ Amoxicillin-clavulanate, $\mathrm{CEF}=$ Ceftriaxone, AZT=Aztreonam, GEN=Gentamicin, CIP=Ciprofloxacin, LEV=Levofloxacin, AMK=Amikacin, NIT=Nitrofurantoin, TSX=Trimethoprim/Sulfamethoxazole, FOS=Fosfomicin, ERT=Ertapenem, COL=Colistin.

Risk factors associated with ESBL-positive UTIs

ESBL-producing E. coli and Klebsiella spp. were detected in $21.5 \%$ of all UTIs $(n=76) ; 76.3 \%$ $(\mathrm{n}=58)$ were CA-UTIs and $23.7 \% \quad(\mathrm{n}=18)$ were HA-UTIs. Infection by ESBL-producing Enterobacteriaceae was more frequent in patients with complicated UTIs (OR=3.65, 95\% $\mathrm{CI}=1.69-7.90, \mathrm{p}=0.001)$, previous use of antibiotics $(\mathrm{OR}=2.71,95 \% \mathrm{CI}=1.54-4.77, \mathrm{p}<0.001)$, type 2 diabetes $(\mathrm{OR}=1.93,95 \% \mathrm{CI}=1.09-3.41$, $\mathrm{p}=0.023$ ), any immunodeficiency ( $\mathrm{OR}=3.84$, 95\% CI=1.34-11.00, $\mathrm{p}=0.008)$, and radiochemotherapy $\quad(\mathrm{OR}=5.49, \quad 95 \% \quad \mathrm{CI}=1.04-29.00$, $\mathrm{p}=0.025$ ) (Table 2). Older patients (age $\geq 60$ years) $(\mathrm{OR}=1.17,95 \% \mathrm{CI}=1.03-1.78, \mathrm{p}=0.013)$ and patients with the presence of a catheter (OR=2.51, 95\% CI=0.83-7.61, $\mathrm{p}=0.049)$ had a higher risk for acquiring an UTI caused by ESBL-producing Enterobacteriaceae in the community (data not shown). 
Table 2. Demographic and clinical data of patients, according to ESBL production.

\begin{tabular}{|c|c|c|c|c|c|}
\hline Characteristic & $\begin{array}{c}\text { Total } \\
(n=353)\end{array}$ & $\begin{array}{c}E S B L \\
(n=76,32.5 \%) \\
\end{array}$ & $\begin{array}{c}\text { non-ESBL } \\
(n=158,67.5 \%)\end{array}$ & P value & OR $(95 \%$ IC $)$ \\
\hline \multicolumn{6}{|l|}{ Species } \\
\hline E. coli & $202(57.2)$ & $71(35.1)$ & $131(64.9)$ & ND & ND \\
\hline Klebsiella spp. & $32(9.1)$ & $5(15.6)$ & $27(84.4)$ & ND & ND \\
\hline \multicolumn{6}{|l|}{ Demographics } \\
\hline Male & $74(21.0)$ & $29(39.2)$ & $45(60.8)$ & 0.136 & $0.65(0.36-1.15)$ \\
\hline Age $\geq 60$ years & $89(25.2)$ & $27(30.3)$ & $62(69.7)$ & 0.584 & $0.85(0.48-1.51)$ \\
\hline \multicolumn{6}{|l|}{ UTI type } \\
\hline Hospital-acquired & $56(15.9)$ & $18(32.1)$ & $38(67.9)$ & 0.951 & $0.98(0.52-1.86)$ \\
\hline Complicated & $173(49.0)$ & $67(38.7)$ & $106(61.3)$ & 0.001 & $3.65(1.69-7.90)$ \\
\hline \multicolumn{6}{|l|}{ Underlying factors } \\
\hline $\begin{array}{l}\text { Previous use of } \\
\text { antibiotics }\end{array}$ & $86(24.4)$ & $40(46.5)$ & $46(53.5)$ & $<0.001$ & $2.71(1.54-4.77)$ \\
\hline Type 2 diabetes & $78(22.1)$ & $33(42.3)$ & $45(57.7)$ & 0.023 & $1.93(1.09-3.41)$ \\
\hline $\begin{array}{l}\text { Arterial } \\
\text { hypertension }\end{array}$ & $48(13.6)$ & $18(37.5)$ & $30(62.5)$ & 0.405 & $1.32(0.68-2.57)$ \\
\hline $\begin{array}{l}\text { Chronic renal } \\
\text { disease }\end{array}$ & $40(11.3)$ & $16(40.0)$ & $24(60.0)$ & 0.265 & $1.49(0.74-3.00)$ \\
\hline Pregnancy & $20(5.7)$ & $4(20.0)$ & $16(80.0)$ & 0.213 & $0.49(0.16-1.53)$ \\
\hline Immunodeficiency & $16(4.5)$ & $10(62.5)$ & $6(37.5)$ & 0.008 & $3.84(1.34-11.00)$ \\
\hline \multicolumn{6}{|l|}{ Urologic alterations } \\
\hline Recurrent UTI & $81(22.9)$ & $27(33.3)$ & $54(66.7)$ & 0.839 & $1.06(0.60-1.88)$ \\
\hline Catheter & $58(16.4)$ & $22(37.9)$ & $36(62.1)$ & 0.307 & $1.38(0.74-2.57)$ \\
\hline Urosepsis & $32(9.1)$ & $9(28.1)$ & $23(71.9)$ & 0.320 & $0.79(0.35-1.80)$ \\
\hline $\begin{array}{l}\text { Obstructive } \\
\text { uropathy }\end{array}$ & $29(8.2)$ & $8(27.6)$ & $21(72.4)$ & 0.548 & $0.77(0.32-1.82)$ \\
\hline Urologic surgery & $23(6.5)$ & $10(43.5)$ & $13(56.5)$ & 0.236 & $1.69(0.71-4.05)$ \\
\hline Lithiasis & $20(5.7)$ & $6(30.0)$ & $14(70.0)$ & 0.805 & $0.88(0.33-2.39)$ \\
\hline $\begin{array}{l}\text { Benign prostatic } \\
\text { hyperplasia }\end{array}$ & $19(5.4)$ & $4(21.1)$ & $15(78.9)$ & 0.267 & $0.53(0.17-1.65)$ \\
\hline Tumor & $15(4.2)$ & $7(46.7)$ & $8(53.3)$ & 0.225 & $1.90(0.66-5.46)$ \\
\hline Neurogenic bladder & $13(3.7)$ & $4(30.8)$ & $9(69.2)$ & 0.892 & $0.92(0.27-3.09)$ \\
\hline $\begin{array}{l}\text { Radiotherapy and/or } \\
\text { chemotherapy }\end{array}$ & $7(2.0)$ & $5(71.4)$ & $2(28.6)$ & 0.025 & $5.49(1.04-29.00)$ \\
\hline
\end{tabular}

ESBL, extended spectrum beta-lactamase; OR, odds ratio; UTI, urinary tract infection; ND, not determined. 
Resistencia antibiótica y agentes beta-lactamasa de espectro extendido en las infecciones... Robles-Torres J. I., et al.

\section{Discussion}

In the present study, we evaluated the epidemiologic characteristics of ESBL-producing agents in UTIs, acquired either in the hospital or the community, in patients at a tertiary care hospital. One-fifth of the UTIs were caused by ESBL-producing strains (21.5\%), which is a higher incidence of ESBL-producing agents in UTIs, compared with the results of other published studies. ${ }^{(11,13,16,17)}$ Nevertheless, previous studies in Mexico have reported alarmingly high incidences of UTIs caused by ESBL-producing E. coli in the community (56.5\%) and in complicated infections (59.8\%). ${ }^{(18,19)}$ Infections caused by ESBL-producing bacteria were more frequent in the community than in our hospital setting (76.3\% and $23.7 \%$, respectively). Indeed, ESBL-producing enterobacteria have been reported to cause up to $41 \%$ of CA-UTIs and up to $26 \%$ of HA-UTIs. ${ }^{(13,17,20,21)}$ A notable increase in CA-UTIs caused by ESBL-producing E. coli was reported in Spain, from $50 \%$ in 2000 to $79 \%$ in $2003(\mathrm{p}<0.001)$. ${ }^{(11)}$ The majority of UTIs detected in our study were CA infections $(65.5 \%)$. E. coli was the most frequent causative agent, both in HA-UTIs and CA-UTIs, although it was more frequently detected in CA infections $(\mathrm{p}<0.001)$. The variety of causative agents of HA-UTIs was more diverse than those acquired in the community, as previously reported. ${ }^{(7)}$

Multiple studies have reported male sex, ${ }^{(13,20,21)}$ advanced age (> 65 years), ${ }^{(20,21)}$ previous hospitalization, ${ }^{(13,20-23)}$ previous antibiotic therapy, ${ }^{(20-23)}$ recurrent UTIs, ${ }^{(13,22)}$ urinary catheterization, ${ }^{(23)}$ diabetes, ${ }^{(13)}$ lithiasis, and immunosuppression as risk factors for ESBL-producing Enterobacteriaceae infections. (17) In our study, complicated UTIs $(\mathrm{p}=0.001)$, previous antibiotic therapy administration $(\mathrm{p}<0.001)$, type 2 diabetes $(\mathrm{p}=0.023)$, any immunodeficiency $(\mathrm{p}=0.008)$, and radiotherapy and/or chemotherapy $(\mathrm{p}=0.025)$ were risk factors for infections by the ESBL-producers, E. coli or Klebsiella spp.

Gram-negative uropathogens are increasingly becoming resistant to currently available antibiotics, including aminoglycosides, sulfonamides and fluoroquinolones. ${ }^{(1,8,9)}$ In our study, E. coli isolates exhibited high resistance to amoxicillin-clavulanic acid, and moderate resistance to gentamicin, aztreonam, and ceftriaxone. Interestingly, resistance levels to ciprofloxacin (complicated UTIs, $64.4 \%$ vs. uncomplicated UTIs, 46.7\%), levofloxacin (complicated UTIs, $62.2 \%$ vs. uncomplicated UTIs, $37.8 \%$ ), fosfomycin (complicated UTIs, $60.7 \%$ vs. uncomplicated UTIs, 64.4\%), and trimethoprim-sulfamethoxazole (complicated UTIs, $59.3 \%$ vs. uncomplicated UTIs, $60.0 \%$ ) were high. However, the Infectious Diseases Society of America (IDSA) guidelines for the treatment of uncomplicated UTIs recommend the administration of nitrofurantoin, trimethoprim/ sulfamethoxazole, fosfomycin, and fluoroquinolones. ${ }^{(24)}$ Therefore, international guidelines seem to be inappropriate in our setting, which limits our therapeutic options.

Even though low resistance rates of uropathogens to fosfomycin are still being reported worldwide, ${ }^{(25)}$ decreasing susceptibility of ESBL-producing E. coli to fosfomycin has been described and limited data has been reported in Latin American countries. ${ }^{(26,27)}$ In addition, as part of the SENTRY Antimicrobial Surveillance Program, bacteria isolated from patients with CA-UTIs in Latin America showed surprisingly high resistance rates to orally administered antimicrobials, especially for trimethoprim/ 
sulfamethoxazole and fluoroquinolones. ${ }^{(28)}$ Those results highlight the need for specific CA-UTI guidelines, based on local susceptibility patterns in geographic regions where elevated antimicrobial resistance may influence prescribing decisions. This situation requires intervention both in the community and in the hospital setting: government regulation strategies are required to minimize the use of antibiotics without a medical prescription and control pharmaceutical industry propaganda and the self-regulation on the part of health professionals, ${ }^{(29)}$ to avoid the unnecessary use of new antibiotics. Within the hospital setting, the surveillance of the prescription of antibiotics to both outpatients and inpatients should also be implemented.

Complicated UTIs caused by E. coli exhibited higher resistance to several antimicrobial agents, including gentamicin $(\mathrm{p}=0.042)$, aztreonam $(\mathrm{p}=0.028)$, ceftriaxone $(\mathrm{p}=0.035)$, ciprofloxacin $(\mathrm{p}=0.041)$, and levofloxacin $(\mathrm{p}<0.001)$. A high percentage of ertapenem, colistin, amikacin, and nitrofurantoin susceptibility was found in our study $(100 \%, 100 \%$, $99.4 \%$, and $92.2 \%$, respectively). The use of those antibiotics is a good option for the empiric treatment of UTIs in the Mexican population. ${ }^{(24)}$

Our study has several limitations. The clonal relationship of isolates, especially of $E$. coli, was not analyzed. Therefore, we could not establish whether there was a high level of genetic diversity between the isolates or whether independent acquisition or cross-transmission occurred. Given the unusually high resistance to fosfomycin detected in the E. coli isolates, further analyses should be performed to characterize those strains and the mechanism of resistance, e.g. the search for fosfomycin-associated genes.

\section{Conclusion}

The emergence of ESBL-producing bacteria in UTIs is a serious health problem, in both our community and our hospital settings. Approximately one out of every five UTIs was caused by ESBLs in our study population. An alarmingly high resistance to antibiotics recommended as first-line empiric therapy in UTIs (fosfomycin, fluoroquinolones, and trimethoprim-sulfamethoxazole) was recognized. Consequently, international guidelines are not suitable for our population, limiting our therapeutic options. The results of our study highlight the need for developing specific guidelines, based on our local susceptibility patterns in geographic regions where elevated antimicrobial resistance may influence therapeutic decisions.

\section{References}

1. Foxman B. The epidemiology of urinary tract infection. Nature Reviews Urology. 2010 Dec;7(12):653-60. doi: https://doi. org/10.1038/nrurol.2010.190

2. Litwin Mark S., Saigal Christopher S., Yano Elizabeth M., Avila Chantal, Geschwind Sandy A., Hanley Jan M., et al. Urologic diseases in america project: analytical methods and principal findings. Journal of Urology. 2005 Mar 1;173(3):933-7. doi: https://doi. org/10.1097/01.ju.0000152365.43125.3b

3. Secretaría de Salud. Información Epidemiológica de Morbilidad. SUIVE/DGE/ Secretaría de Salud/Estados Unidos Mexicanos 2017. 2017. [accessed 25 Apr 2020] Available from: https://www.gob.mx/salud/acciones-yprogramas/anuarios-de-morbilidad-1984-2018

4. Grabe $\mathbf{M}$, Bjerklund-Johansen TE, Botto $\mathbf{H}$, 
Resistencia antibiótica y agentes beta-lactamasa de espectro extendido en las infecciones... Robles-Torres J. I., et al.

Çek M, Naber KG, Tenke P, et al. Guidelines on urological infections. European association of urology. 2015;182.

5. Naber KG, Schito G, Botto H, Palou J, Mazzei T. Surveillance study in Europe and Brazil on clinical aspects and Antimicrobial Resistance Epidemiology in Females with Cystitis (ARESC): implications for empiric therapy. Eur Urol. 2008 Nov;54(5):1164-75. doi: https://doi. org/10.1016/j.eururo.2008.05.010

6. Nicolle LE. A Practical Guide to the Management of Complicated Urinary Tract Infection. Drugs. 1997 Apr 1;53(4):583-92. doi: https://doi. org/10.2165/00003495-199753040-00004

7. Laupland KB, Ross T, Pitout JDD, Church DL, Gregson DB. Community-onset Urinary Tract Infections: A Population-based Assessment. Infection. 2007 Jun 1;35(3):150. doi: https:// doi.org/10.1007/s15010-007-6180-2

8. Boucher HW, Talbot GH, Bradley JS, Edwards JE, Gilbert D, Rice LB, et al. Bad Bugs, No Drugs: No ESKAPE! An Update from the Infectious Diseases Society of America. Clin Infect Dis. 2009 Jan 1;48(1):1-12. doi: https:// doi.org/10.1086/595011

9. Zowawi HM, Harris PNA, Roberts MJ, Tambyah PA, Schembri MA, Pezzani MD, et al. The emerging threat of multidrug-resistant Gram-negative bacteria in urology. Nature Reviews Urology. 2015 Oct;12(10):570-84. doi: https://doi.org/10.1038/nrurol.2015.199

10. Tal Jasper R, Coyle JR, Katz DE, MarchaimD. The complex epidemiology of extended-spectrum $\beta$-lactamase-producing Enterobacteriaceae. Future Microbiology. 2015 May 1;10(5):81939. doi: https://doi.org/10.2217/fmb.15.16

11. Calbo E, Romaní V, Xercavins M, Gómez L, Vidal CG, Quintana S, et al. Risk factors for community-onset urinary tract infections due to
Escherichia coli harbouring extended-spectrum $\beta$-lactamases. J Antimicrob Chemother. 2006 Apr 1;57(4):780-3. doi: 10.1093/jac/dk1035

12. Rodríguez-Baño J, Navarro MD, Romero L, Muniain MA, Perea EJ, Pérez-Cano R, et al. Clinical and Molecular Epidemiology of Extended-Spectrum $\beta$-Lactamase-Producing Escherichia coli as a Cause of Nosocomial Infection or Colonization: Implications for Control. Clin Infect Dis. 2006 Jan 1;42(1):3745. doi: https://doi.org/10.1086/498519

13. Briongos-Figuero LS, Gómez-Traveso T, Bachiller-Luque P, González MD-G, Gómez-Nieto A, Palacios-Martín $T$, et al. Epidemiology, risk factors and comorbidity for urinary tract infections caused by extendedspectrum beta-lactamase (ESBL)-producing enterobacteria. International Journal of Clinical Practice. 2012;66(9):891-6. doi: https://doi. org/10.1111/j.1742-1241.2012.02991.x

14. Saltoglu N, Karali R, Yemisen M, Ozaras R, Balkan II, Mete B, et al. Comparison of community-onset healthcare-associated and hospital-acquired urinary infections caused by extended-spectrum beta-lactamaseproducing Escherichia coli and antimicrobial activities. International Journal of Clinical Practice. 2015;69(7):766-70. doi: https://doi. org/10.1111/ijcp.12608

15. Clinical \& Laboratory Standards Institute (CLSI). M100Ed30 | Performance Standards for Antimicrobial Susceptibility Testing, 30th Edition. Wayne, Pennsylvania, USA.; 2017. [accessed 25 Apr 2020] Available from: https:// clsi.org/standards/products/microbiology/ documents/m100/

16. Blanco VM, Maya JJ, Correa A, Perenguez M, Muñoz JS, Motoa G, et al. [Prevalence and risk factors for extended-spectrum 
$\beta$-lactamase-producing Escherichia coli causing community-onset urinary tract infections in Colombia]. Enferm Infecc Microbiol Clin. 2016 Nov;34(9):559-65. doi: https://doi. org/10.1016/j.eimc.2015.11.017

17. Medina-Polo J, Arrébola-Pajares A, PérezCadavid S, Benítez-Sala R, Sopeña-Sutil R, Lara-Isla A, et al. Extended-Spectrum Beta-Lactamase-Producing Bacteria in a Urology Ward: Epidemiology, Risk Factors and Antimicrobial Susceptibility Patterns. UIN. 2015;95(3):288-92. doi: https://doi. org/10.1159/000439441

18. Hernández-Vergara JA, Martínez-Santos VI, Radilla-Vázquez RB, Silva-Sánchez J, Vences-Velásquez A, Castro-Alarcón N. Characterization of Escherichia coli clinical isolates causing urinary tract infections in the community of Chilpancingo, Mexico. Int Microbiol. 2016 Dec;19(4):209-15. doi: https:// doi.org/10.2436/20.1501.01.279

19. Cornejo-Dávila V, Palmeros-Rodríguez MA, Uberetagoyena-Tello de Meneses I, MayorgaGómez E, Garza-Sáinz G, Osornio-Sánchez V, et al. Management of complicated urinary tract infections in a referral center in Mexico. Int Urol Nephrol. 2015 Feb 1;47(2):229-33. doi: https:// doi.org/10.1007/s11255-014-0883-y

20. Colodner R, Rock W, Chazan B, Keller N, Guy N, Sakran W, et al. Risk Factors for the Development of Extended-Spectrum Beta-Lactamase-Producing Bacteria in Nonhospitalized Patients. Eur J Clin Microbiol Infect Dis. 2004 Mar 1;23(3):163-7. doi: https://doi.org/10.1007/s10096-003-1084-2

21. Ben-Ami R, Rodríguez-Baño J, Arslan H, Pitout JDD, Quentin C, Calbo ES, et al. A Multinational Survey of Risk Factors for Infection with Extended-Spectrum $\quad \beta$-Lactamase-Producing Enterobacteriaceae in Nonhospitalized Patients.
Clin Infect Dis. 2009 Sep 1;49(5):682-90. doi: https://doi.org/10.1086/604713

22. Alcántar-Curiel MD, Alpuche-Aranda CM, Varona-Bobadilla HJ, Gayosso-Vázquez C, Jarillo-Quijada MaD, Frías-Mendivil $M$, et al. Risk factors for extended-spectrum b-lactamases-producing Escherichia coli urinary tract infections in a tertiary hospital. Salud Publica Mex. 2015 Sep 12;57(5):412. doi: http://dx.doi.org/10.21149/spm.v57i5.7621

23. Lee DS, Lee CB, Lee S-J. Prevalence and Risk Factors for Extended Spectrum Beta-LactamaseProducing Uropathogens in Patients with Urinary Tract Infection. Korean Journal of Urology. 2010 Jul 1;51(7):492-7. doi: https:// doi.org/10.4111/kju.2010.51.7.492

24. Gupta K, Hooton TM, Naber KG, Wullt B, Colgan R, Miller LG, et al. International Clinical Practice Guidelines for the Treatment of Acute Uncomplicated Cystitis and Pyelonephritis in Women: A 2010 Update by the Infectious Diseases Society of America and the European Society for Microbiology and Infectious Diseases. Clin Infect Dis. 2011 Mar 1;52(5):e103-20. doi: https://doi.org/10.1093/cid/ciq257

25. Vardakas KZ, Legakis NJ, Triarides N, Falagas ME. Susceptibility of contemporary isolates to fosfomycin: a systematic review of the literature. Int $\mathrm{J}$ Antimicrob Agents. 2016 Apr;47(4):269-85. doi: https://doi. org/10.1016/j.ijantimicag.2016.02.001

26. Sorlozano A, Jimenez-Pacheco A, de Dios Luna Del Castillo J, Sampedro A, MartinezBrocal A, Miranda-Casas C, et al. Evolution of the resistance to antibiotics of bacteria involved in urinary tract infections: a 7-year surveillance study. Am J Infect Control. 2014 Oct;42(10):1033-8. doi: https://doi. org/10.1016/j.ajic.2014.06.013 
Resistencia antibiótica y agentes beta-lactamasa de espectro extendido en las infecciones... Robles-Torres J. I., et al.

27. Salles MJC, Zurita J, Mejía C, Villegas MV. Resistant Gram-negative infections in the outpatientsettinginLatinAmerica.Epidemiology \& Infection. 2013 Dec;141(12):2459-72. doi: https://doi.org/10.1017/S095026881300191X

28. Andrade SS, Sader HS, Jones RN, Pereira AS, Pignatari AC, Gales AC. Increased resistance to first-line agents among bacterial pathogens isolated from urinary tract infections in Latin America: time for local guidelines? Memórias do Instituto Oswaldo Cruz. 2006 Nov;101 (7):741-8. doi: https://doi.org/10.1590/S007402762006000700006

29. Brennan TA, Rothman DJ, Blank L, Blumenthal D, Chimonas SC, Cohen JJ, et al. Health Industry Practices That Create Conflicts of Interest: A Policy Proposal for Academic Medical Centers. JAMA. 2006 Jan 25;295(4):429-33. doi: https:// doi.org/10.1001/jama.295.4.429 